\title{
Risk Management \& Financial Performance of Commercial Banks in Pakistan
}

\section{Ghulam Saghir and Emad Tabassam $\mathrm{Ch}^{* *}$}

\begin{abstract}
The main objective of this study is to find out how, the two different types of risks, i.e. Liquidity Risk $\mathcal{E}$ Credit Risk, affect the overall profitability/financial performance of commercial banks in Pakistan. We used methods that were applicable on a panel data for long run and short run time specifications. Thirtythree scheduled banks listed with the SBP, as of December 2018 have been used for the purpose of the data analysis. The panel data that is used for this study stretches across a period of 10 years, with 33 cross sections. The findings of this current study revealed that the financial performance of the banks present in Pakistan is negatively, and significantly influenced by the credit risk. In addition to this, it was revealed that the lesser the non-performing loans, the lower the risk factor that is experienced. The financial risk comprising of credit risk and liquidity risk tends to have a significantly robust impact on the overall enactment of the commercial banks in Pakistan. This study will prove beneficial for the top management of the financial institutions developing economies, as it will enhance their existing knowledge regarding the impact of financial risk, which will eventually infiltrate into the intensity and quality of the financial performance of the banks. This will also enable banks, and other financial institutions to involve all the relevant stakeholders, in order to determine how they can minimize the effects of the financial risk, so as to maximize the overall returns.
\end{abstract}

Keywords: Credit risk, liquidity risk, financial performance, commercial banks, risk management

JEL Classification: G30, G32, L25

1. Introduction

It is a well-known fact that banks, and banking institutions, play an integral part in the financial sector of any economy as they perform a considerable amount of critical activities on both the flanks of the balance

\footnotetext{
* Assistant Professor, University of Central Punjab, Lahore, Pakistan.

** Head - Retail \& Consumer Banking, National Bank of Pakistan, Lahore, Pakistan.
} 
sheet. An efficient banking sector is crucial for the economic growth of any nation. Moreover, the divisions in banking sector across the world are now becoming more integrated, with every passing day. This is, therefore, resulting in an increased complexity of the operational framework of the banking institutions. Considering that the same trend will follow suit, regulators are now regularly working on finding techniques for better risk management. This is being considered, in order to minimize the effect of the various types of risks that might have an effect on the overall profitability \& financial performance of the banking institutions. In this context, Diamond and Rajan (2001) asserted that, on the assets side, the banks manage the flow of funds by lending cash to the users, while augmenting the credit flow in the economy. Moreover, it provides liquidity to the investors when the liability side of the balance sheet is considered. Banks also perform various other activities. For instance, facilitating the settlement and payment systems, supporting the transfer of several goods and services, etc. This diverse nature of activities performed by the banks, unearth and expose them to different kinds of risks.

SBP has defined risk as (2003), "the adverse influence on profitability of various discrete causes of uncertainty". Al-Tamimi and AlMazrooei (2007) emphasized that researchers have proclaimed that risk can be classified in two categories; unsystematic risk and systematic risk. The authors state that the systematic risk is linked to the entire market, or the overall economy. It is also known as "undiversifiable", "volatility" or "market" risk. This type of risk affects the overall market, and not just a particular industry, and it cannot be eluded by diversification. Whereas, unsystematic risk is associated with only a particular firm, or a certain asset, and it can be avoided with the aid of diversification activities. In addition to this, it may also be known as "diversifiable" risk (Al-Tamimi \& Al-Mazrooei, 2007).

It is intriguing to realise that all the financial institutions tend to experience financial risks that are common in nature. For instance, banks and microfinance institutions share common risks, that are most likely to be credit risks, and liquidity risks. Liquidity risk, as proclaimed by (Jenkinson, 2008), constitutes of a situation where a bank may not meet its debts, as the creditors may demand their funds in an untimely manner. This eventually leads to the sale of assets on an urgent basis, which in turn, adversely affects the profitability of the bank (Chaplin, Emblow \& Michael. 2000). Lopez and Saidenberg (2000) asserted that credit risk is essentially demarcated as the level of fluctuations in the value of the derivatives and 
the liability instruments, due to the variabilities in the credit quality of the debtors, as well as their counterparties.

We can assess from the earlier review of the literature that prior research has been conducted in the discipline pertaining to bank risks. However, there is a lack of comprehensive insight that is available in any of the extant studies that are based on the topic of risk. Most of the research mentioned above is primarily concentrated towards credit risk, and misses out the elements of other risks that a bank might be exposed to. The current study has a broader scope, and has covered two major risks, i.e. the credit risk and liquidity risk, that are faced by the banking sector. Therefore, this approach and decision has made the current study more comprehensive in nature. Moreover, when considering the Pakistani context, I found only a few studies which seem to have captured the effect of these risks, on the financial performance of the banks. Also, this study has used the most recent data from the year 2008 to 2018, mainly in order to evaluate the impact of the risks on the financial performance of the commercial banks in Pakistan. Furthermore, in order to check for the robustness, we have also tested all the models in a fixed time and fixed cross-sectional settings. Therefore, the current study is aimed towards filling up the existing gaps by evaluating the effect of the two types of risks on the financial performance of commercial banks in Pakistan. For the purpose of this study, the population that is considered, includes all the commercial banks, which are registered and are operational during the years 2017 till 2018. Other than that, the time series \& the cross-sectional data available in the annual reports that are published by the banks and various publications of SBP have been used for the purpose of carrying out the secondary data analysis.

This study helps the regulators and policy makers to get a better understanding of the overall scope of the financial risks, and also checks the suitability of the risk management system that they have put in place for the industry. Also, this study could provide a foundation for quantifying the risk exposures. It will also prove to be beneficial for the top management of the financial institutions of developing economies, as it will enhance their existing knowledge regarding the influence of financial risks on financial enactment of the banks.

The rest of the paper is organized as follows. Section 2 highlights the previous studies. Moving on, section 3 of the study describes the data and the methodology used. Section 4 presents the results and the empirical findings, and also discusses the revelations that have been made. Lastly, section 5 provides the conclusion and the future research directions. 


\section{Literature Review}

In their study, Cebenoyan and Strahan (2004) asserted that banking is the only sector of the economy where several risks are managed on a simultaneous basis. On a usual basis, banks and financial institutions are known to handle various, and ostensibly contrasting needs. In this regard, Kashyap, Rajan and Stein (2002) proclaimed that banks are always prepared to offer liquidity through the checking account, especially when their depositors demand for it. In addition to this, they are always ready to extend credit and liquidity to the debtors, by making sure that the lines of credit are not disrupted. Due to these diverse roles of banks, they are always apprehensive about the liquidity and solvency issues that they might have to encounter.

Drehmann, Sorensen and Stringa (2010) emphasized on the importance of credit risk, which is one of the most significant risks that are encountered by the banks. The authors asserted that the profitability, and net worth of the banks are not only dependent upon the default risks, but also upon the overall quality of the credit, items of the off-balance sheet, liabilities and the repricing characteristics of its book.

The bank's profitability is dependent upon the capability of the bank to predict, evade and evaluate risks. Keeping this in mind, an increasing number of banks have been reported to over-stretch their current human resource capacity, as asserted by Sanusi (2002). This has lead to various problems which include a poor credit appraisal system, accrual of poor credit quality, and financial crimes, etc. Consequently, this has also resulted in a growing number of banks that are distressed and crumbling under the pressure to perform. The author also identified certain other factors such as poor management, opposing ownership effects, and other types of insider exploitations, combined with political concerns and extended court processes regarding debt recovery, which escalate these systematic failures of banking intuitions. Another study conducted by Abiola and Olausi (2014) shed light on the influence of credit risk management on the banks' profitability in Nigeria. The findings of this study suggested that there is a significant connection between the banks' effectiveness, and the management of credit risk. Similarly, Cooper et al. (2003) conjectured that the variations in the health of the banks' credit portfolio might be imitated by the variations in the credit risk, which could well have an impact on the performance of the banks. A research conducted by Pasiouras (2008) estimated a negative connection between the credit risk and the banks' profitability. This primarily means that the 
more the banks were exposed to the high risk loans, the greater the accrual of unpaid loans, and therefore, the lesser the profitability of the banks.

Moreover, a study conducted by Musyoki and Kadubo (2012) highlighted the influence of credit risk management on the banks' financial performance in Kenya. The findings revealed that there was an inverse influence of all the parameters of risk management, on the financial enactment of the banks. In addition to this, it was revealed that the default rate had the utmost influence on the performance of the banks as well. Similarly, a study conducted on the banking sector of Pakistan by Abbas, Haider and Rana (2014) estimated the impact of credit risk on the banks' performance. The authors concluded that this particular risk has a negative influence on the performance, and the success of a bank is dependent upon the effective management of this risk.

According to the Central Bank of Barbodas (2008), liquidity issues might affect the earnings, as well as the bank's capital. In situations that are even worse, it may also result in the solvent bank's downfall. In the course of ongoing liquidity issues, banks tend to arrange funds from the financial market, even under the highest cost that is being offered to them. This extra borrowing may eventually put the capital of the bank at risk. Moreover, this will result in an increased debt-equity ratio, which will eventually hinder the banks' capacity to maintain an optimal capital structure.

Falconer (2001) conjectured that liquidity risk could result in the fire sale of assets that could weaken the banks' capital base as well. Similarly, Diamond and Rajan (2001) also asserted that, in order to keep their position secure, banks tend to display a refusal to borrow funds, even if they have high liquidity needs. This results in the opportunity cost to the banks. Moreover, Holmstrom and Tirole (2000) proclaimed that a bank would never invest all its assets in long-term investments. The authors also asserted that various resources are only invested in short-term liquid investments. This strategy offers a cushion over the expected liquidity shock that might come around in the future. At another instance, Athanasoglou, Delis and Staikouras (2006) viewed liquidity risk as a significant factor, defining the banks' productivity, simply due to the notion that liquidity risk can be a valid cause of bank failure. The liquidity risk arises due to the incompetence of the banks to manage the reductions on the liability side of their balance sheet, or the surges erupting on the assets' side of their balance sheet. Banks often tend to hold liquid assets that can be easily converted into cash, mainly in order to avoid bankruptcy. Nonetheless, liquid assets are commonly linked to a lower rate of return, therefore, the higher the liquidity, the lower the profitability. These findings are in line with the revelations that have 
been made by Goddard, Molyneux and Wilson (2004), who proved that there happens to be a negative association between the liquidity level and the banks' performance. Furthermore, Arif and Anees (2012) evaluated the liquidity risk and the banking system performance in Pakistan. The results showed that the banks' performance is significantly affected by the liquidity risk, along-with two other factors, i.e. the liquidity gap and the NPLs, which play a significant role in aggravating the liquidity risk. In addition to this, these two factors have a negative association with the profitability of a bank.

\section{Methodology}

\subsection{Data}

For the purpose of this study, we utilised the secondary data that was available to us; the data was gathered from the financial statements and the banks' annual reports, over a time period spanning to a total of ten years. The panel data was then analysed using the regression equations that were solved in Eviews7. Moving on, 33 scheduled banks were listed with the SBP, as of Dec 2018. Among these banks, there were 5 full fledge Islamic banks, which were also being included for the purpose of this study. It is noteworthy here that other commercial banks are also offering Islamic banking services to the masses, but for reporting purposes their financials have been consolidated and count not be bifurcated. Therefore, all the other scheduled banks listed with the SBP, as of Dec 2018, which includes 5 "Public Sector Commercial Banks", 4 "Specialized Banks", 15 "Domestic Private banks" \& 4 "Foreign banks" have been considered as the target population for this study.

\subsection{Model Specification}

We utilised the panel data in order to include the time effects that were applicable to this study. One of the major advantages of using the panel data is their ability to control the individual heterogeneity.

In order to evaluate the impact of the risk on the financial enactment of the banks, this study applied the short run panel model, and the long run panel model. The long run model assumed that the performance of the current period was not affected by the last period's performance. Whereas, the short run model assumed that the last period's performance left an impact on the performance of the current period. Thus, the lagged dependant explanatory variable was incorporated in the short run model. 


\subsubsection{Panel Model 1}

The first goal of this study was to examine the stimulus credit risk, and its impact on the financial enactment of the commercial banks that are situated in Pakistan. In the first model, the financial performance was taken as the dependent variable, and the indicators of the credit risk were taken as the independent variables. We also assumed that there happens to be a multiplicative Cobb Douglas functional relationship between the independent and the dependent variables, as shown in equation 1:

$$
\mathrm{ROE}=\mathrm{f}(\mathrm{CAR}, \mathrm{LLP}, \mathrm{AQ}, \mathrm{LDR})
$$

Therefore, keeping this under consideration, the long run model would be:

$R O E_{i t}=\beta_{o}+\beta_{1} C A R_{i, t}+\beta_{2} L L P_{i, t}+\beta_{3} A Q_{i, t}+\beta_{4} L D R_{i, t}+\alpha_{i}+\varepsilon_{i, t}$

And the short run would be:

$R O E_{i t}=\beta_{o}+\lambda R O E_{i t-1}+\beta_{1} C A R_{i, t}+\beta_{2} L L P_{i, t}+\beta_{3} A Q_{i, t}+\beta_{4} L D R_{i, t}+\alpha_{i}+\varepsilon_{i, t}$

Here, $i=1,2, \ldots \quad t=1,2 \ldots . .10$

In the above model, the $\mathrm{ROE}_{\text {it }}$ signifies the performance of the bank, which is denoted by $\mathrm{I}$, at time $\mathrm{t}, \beta_{\mathrm{o}}$ is the constant, and $\beta_{\mathrm{i}}$ represents the co-efficient of all the independent variables. The ROE it-1 represents the lagged performance of the bank.

\subsubsection{Panel Model 2}

The second goal of this study was to examine the influence of the liquidity risk on the financial performance of the bank. For this, the model used was:

$$
\mathrm{ROE}=\mathrm{f}\left(\mathrm{DTAR}, \mathrm{EA} \_\mathrm{TA}, \mathrm{NE} \_ \text {Deposits }\right)
$$

The long run model was:

$R O E_{i t}=\lambda_{o}+\lambda_{1} D T A R_{i, t}+\lambda_{2} E A_{-} T A_{i, t+} \lambda_{3} N E_{-}$Deposits $_{i, t+} \theta_{i}+\varepsilon_{i, t}$

And the short run was:

$R O E_{i t}=\lambda_{0}+\lambda R O E_{i t-1}+\lambda_{1} D T A R_{i, t}+\lambda_{2} E A \_T A_{i, t}+\lambda_{3} N E_{-}$Deposits $i+\theta_{i}+\varepsilon_{i, t}$

In the above model, $\mathrm{ROE}_{\text {it }}$ signifies the performance of bank $\mathrm{I}$, at time $t, \lambda_{o}$ is the constant, and $\lambda_{i}$ represented the co-efficient of all the independent variables. The $\mathrm{ROE}_{\mathrm{it}-1}$ is the lagged performance of the bank. Moreover, DTAR is the deposits to total assets ratio, EA_TA is the earning 
assets to total assets ratio, and NE_Deposits (Net equity to deposits) is the proxy used for "net stable funding ratio" of bank, at a particular time period t. $\varepsilon_{i, t}$ is the error term.

\subsection{Descriptive Statistics}

The following section highlights the descriptive analysis of the data used for the study variables. The summary of the statistics of the data is appended below.

Table 1: Summary of Descriptive

\begin{tabular}{lccccc}
\hline Variables & Obs. & Mean & Std. Dev. & Max. & Min. \\
\hline ROE & 344 & 0.045 & 0.267 & 0.373 & -2.001 \\
NPLR & 344 & 0.085 & 0.097 & 1.000 & 0.000 \\
LDR & 344 & 0.690 & 1.233 & 23.111 & 0.013 \\
LLPR & 344 & 0.003 & 0.005 & 0.045 & 0.000 \\
NE_DEPOSITS & 344 & 1.269 & 17.506 & 323.778 & 0.004 \\
CAR & 344 & 0.558 & 3.406 & 46.206 & -0.064 \\
DTAR & 344 & 0.701 & 0.165 & 0.909 & 0.002 \\
EA_TA & 344 & 0.834 & 0.137 & 0.979 & 0.048 \\
\hline
\end{tabular}

The table above shows the summary of the statistics for the variables that have been used. The overall mean values of the ROE, CAR, NLPR, LLPR, LDR, DTAR were 4.5\%, 55.8\%, 8.5\%, 0.3\%, 6.90\%, 70.1\% respectively, as visible in Table 4.2. Therefore, over time, the banks in Pakistan have shown a positive trend of profitability, and they remain effectively capitalized. However, the asset quality seems to have declined over time.

\section{Results and Empirical Findings}

\subsection{Panel Regression Results}

This section presents the results of the main regressions that are tested in order to assess the relationship between the different risks, and the subsequent performance of Pakistani banks. Firstly, the Hausman test was conducted to assess whether the random or the fixed effect model was appropriate in order to evaluate both the long run and the short run model. We conducted the Hausman test before every long run and short run model. Irrespective of Hausman's test, a fixed-fixed model was also conducted, in order to enhance or improve our results. The impact of each 
risk on the ROE of the commercial banks in Pakistan has also been examined in this study. The following section presents the summary of all the proposed models. Moreover, the Hypothesis have been tested in both the long run, and the short run.

\subsubsection{Influence of Credit Risk on Financial Performance}

In order to test the first hypothesis, that too both in the long run and the short run, equation 1 and equation 2, in the Panel Model 1, had been tested. Firstly, we conducted the Hausman test on the long run model, comprising of the credit risk components as the independent variables, and the $\mathrm{ROE}$ as the dependant variables.

The null hypothesis for Hausman test was:

- $\mathrm{H}_{0}$ : The Random Effect model is appropriate.

Moreover, we also conducted the Hausman test in Eviews7, and the results of the Hausman test are shown below in Table 2

Table 2: (Panel Model 1) - Long Run and Short Run (Hausman Test)

\begin{tabular}{lcc}
\hline & Chi-Sq. Statistic & Prob. \\
\hline Long Run & 37.750 & 0.000 \\
Short Run & 6.216 & 0.286 \\
\hline
\end{tabular}

From the table above, we can assess that the p-value is less than 0.1, so the null hypothesis is rejected. This primarily means that the random effect model is not appropriate for the long run model, so we concluded that the fixed effect specification should be preferred over the random effect condition. Also, we could also assess that the p-value is greater than 0.1 in the case of the short run model. So, we failed to reject the null hypothesis of the Hausman test. This means that the random effect model is apt for the short run model, and it should thus be inferred. The fixed effect model and the random effect model was thus conducted in order to test the connection between the credit risk components and the ROE, in the end. Table 3 highlights the results of the fixed effect model, and Table 4 reflects the results for the random effect model for the short-run model. 
Table 3: (Panel Model 1) Fixed effects Estimates - Long Run

\begin{tabular}{lcccc}
\hline Variable & Coefficient & Prob. & t-Statistic & Std. Error \\
\hline C & 0.122906 & 0.0000 & 5.107919 & 0.024062 \\
CAR & 0.033525 & 0.0000 & 4.469117 & 0.007501 \\
LLPR & 10.90943 & 0.0002 & 3.815661 & 2.859120 \\
NPLR & -1.383508 & 0.0000 & -6.469873 & 0.213838 \\
LDR & -0.021201 & 0.1855 & -1.326896 & 0.015978 \\
R $^{2}$ & 0.221979 & & & \\
\hline
\end{tabular}

We can clearly see that all dimensions of credit risk happen to have a significant link with the ROE, except that in the Loan-deposit ratio. Moreover, all the other dimensions considered have a statistically significant link, with the return on the equity, with a p-value of 0.000 . However, the relationship between CAR, LLPR and ROE are positive. This means that the greater the CAR and LLPR ratio, the greater the ROE, and thus, the greater the performance of the commercial banks. Whereas, the NPLR and LDR are negatively related with the ROE. The co-efficient of the CAR is 0.0335 , with a p-value of 0.000 , which means that a one-unit increase in the capital adequacy ratio increases the return on the equity by 0.03 units, while holding all the other aspects constant.

Furthermore, the table also shows that the asset quality, which is being measured through the non-performing loans ratio, has a negative link with the return on equity. The co-efficient is -1.38 , with a corresponding $\mathrm{p}$-value of 0.000 . This means that there exists a significant, negative relationship with the return on equity. It indicates that the higher loan losses leads to a drop in the profitability of the banks. Now, the loandeposit ratio has a negative, but insignificant relationship with the return on equity, as indicated by the p-value, which did not come out to be significant at any level of significance. This indicates that in the long run, the loan-deposit ratio has no influence on the performance of the commercial banks in Pakistan. Whereas, the LLPR ratio ended up having a positive association with the performance of the banks with a co-efficient of 10.91, and it is significant at a $1 \%$ significance level. 
Table 4: (Panel Model 1) - Random Effect Estimates- Short Run

\begin{tabular}{lcccc}
\hline \multicolumn{1}{c}{ Variable } & Coefficient & Prob. & t-Statistic & Std. Error \\
\hline C & 0.044869 & 0.0393 & 2.070374 & 0.021672 \\
ROE(-1) & 0.660185 & 0.0000 & 18.84279 & 0.035036 \\
CAR & 0.009361 & 0.0756 & 1.782916 & 0.005250 \\
LLPR & 4.302408 & 0.0247 & 2.257024 & 1.906231 \\
NPLR & -0.369423 & 0.0177 & -2.384297 & 0.154940 \\
LDR & -0.007700 & 0.4595 & -0.740564 & 0.010397 \\
R $^{2}$ & 0.601618 & & & \\
\hline
\end{tabular}

In the short run model, the lagged variable of the Return on Equity had been added to the model. It is evident from the table that the lagged ROE has a significant impact on the current period's ROE. Similar to the long run model, the components of the credit risk had the same relationship with the return on equity, but with different corresponding pvalues. For instance, the CAR ratio was significant at a10 percent significance level, as the p-value is now 0.07 . The loan-deposit ratio remained insignificant, in even short run model. However, the LLPR also has a changed significance level in the short run model, as indicated by the $\mathrm{p}$ value of 0.02 , which is greater than 0.01 . Thus, the LLPR is now significant at a $5 \%$ level.

Irrespective of the Hausman test, we conducted a fixed-fixed model for the long run specifications, as well as the short run specification. The results are shown in the table 5 below.

Table 5: (Panel Model 1) Fixed-Fixed Estimates - Long Run and Short run

\begin{tabular}{lccccc}
\hline & Variable & Coefficient & Prob. & t-Statistic & Std. Error \\
\hline \multirow{4}{*}{ Long Run } & C & 0.161264 & 0.0000 & 5.927493 & 0.027206 \\
& CAR & 0.047767 & 0.0000 & 4.362542 & 0.010949 \\
& LLPR & 7.448398 & 0.0220 & 2.301857 & 3.235821 \\
& NPLR & -1.795110 & 0.0000 & -5.847039 & 0.307012 \\
& LDR & -0.021373 & 0.1338 & -1.503526 & 0.014215 \\
& $\mathrm{R}^{2}$ & 0.560542 & & & \\
& $\mathrm{C}$ & 0.111847 & 0.0000 & 4.549548 & 0.024584 \\
& ROE(-1) & 0.457844 & 0.0000 & 10.35113 & 0.044231 \\
& CAR & 0.033203 & 0.0005 & 3.552742 & 0.009346 \\
& LLPR & 5.158557 & 0.0553 & 1.924845 & 2.679986 \\
& NPLR & -1.129036 & 0.0000 & -4.134927 & 0.273049 \\
& LDR & -0.019084 & 0.0850 & -1.728792 & 0.011039 \\
& R ${ }^{2}$ & 0.723552 & & & \\
\hline
\end{tabular}


Here, in the above table you can see that the association between each component of the credit risk, and the return on the equity has not changed, as indicated by the sign of each of the co-efficient. Moreover, the significance has not changed as well, in both the long run and the short run models. However, it is evident from the table above, that the R-squared has shown a considerable improvement from 60.1 percent to 72.3 percent. This means that the discrepancy in the ROE is now more enlightened by the independent variables that are present in our short run model. Similarly, the same scenario is applicable to the long run model as well.

\subsubsection{Influence of Liquidity Risk on Financial Performance}

In order to test the hypothesis, both in the long run and the short run, equations 3 and 4 in the Panel Model 2 have been tested. For this purpose we initially conducted the Hausman test on the long run model, comprising of the liquidity risk components that were taken as the independent variables, and the ROE as the dependant variables.

The null hypothesis for the Hausman test remained the same. The outcomes of the Hausman test are displayed below in Table 6 .

Table 6: (Panel Model 2) - Long Run and Short Run (Hausman Test)

\begin{tabular}{lcc}
\hline & Chi-Sq. Statistic & Prob. \\
\hline Long Run & 14.709 & 0.002 \\
Short Run & 2.610 & 0.6251 \\
\hline
\end{tabular}

From the table above, we can assess that the p-value is less than 0.1, therefore, we are able to reject the null hypothesis. It means that the random effect model is not appropriate for the long run model. Also, we can also assess that the p-value is greater than 0.1 , in case of the short run model, so we fail to reject the null hypothesis of the Hausman test. Thus, we concluded that the fixed effect specification should ideally be preferred over the random effect specification in the case where the long run is taken into consideration, and the random effect model is suitable for the short run model. The results of the fixed effect model, and the random effect model are shown in table 7 and table 8, respectively. 
Table 7: (Panel Model 2) - Fixed Effect Estimates - Long Run

\begin{tabular}{lcccc}
\hline Variable & Coefficient & Prob. & t-Statistic & Std. Error \\
\hline C & 0.069015 & 0.4582 & 0.742657 & 0.092930 \\
DTAR & -0.089342 & 0.3931 & -0.855131 & 0.104478 \\
EA_TA & 0.047112 & 0.7202 & 0.358474 & 0.131424 \\
NE_DEPOSIT & -0.000632 & 0.4689 & -0.725058 & 0.000872 \\
S & & & & \\
R $^{2}$ & 0.093914 & & & \\
\hline
\end{tabular}

We could infer from the results that all the dimensions of the liquidity risk do not have a significant association with return on equity. Therefore, this indicates that in the long run, the deposits to the total assets ratio (DTAR), the earning assets to the total assets ratio, and the net equity to the total deposits, do not have a significant influence on the performance of the commercial banks in Pakistan.

Table 8: (Panel Model 2) - Random Effect Estimates- Short Run

\begin{tabular}{lcccc}
\hline Variable & Coefficient & Prob. & t-Statistic & Std. Error \\
\hline & & & & \\
C & -0.027251 & 0.6668 & -0.430902 & 0.063241 \\
ROE(-1) & 0.694533 & 0.0000 & 20.80325 & 0.033386 \\
DTAR & -0.071504 & 0.2740 & -1.095770 & 0.065255 \\
EA_TA & 0.121963 & 0.1437 & 1.465904 & 0.083200 \\
NE_DEPOSITS & -0.000103 & 0.8447 & -0.196097 & 0.000525 \\
R $^{2}$ & 0.591191 & & & \\
\hline
\end{tabular}

In the short run model, it is evident from the table that the lagged ROE has a significant impact on the current period's ROE. All the three components of the liquidity risk have turned out to have a non-significant relationship with the return on equity. Moreover, all the components remained insignificant, even in the short run model.

Regardless of the Hausman test, we conducted a fixed-fixed model for the long run, as well as the short run specifications. The results are shown in the table 9 below: 
Table 9: (Panel Model 2) - Fixed - Fixed Estimates- Long Run

\begin{tabular}{cccccc}
\hline & Variable & Coefficient & Prob. & t-Statistic & Std. Error \\
\hline \multirow{4}{*}{ Long Run } & C & 0.640555 & 0.0025 & 3.043500 & 0.210467 \\
& DTAR & -0.523627 & 0.0031 & -2.977557 & 0.175858 \\
& EA_TA & -0.274458 & 0.2323 & -1.196991 & 0.229290 \\
& NE_DEPOSITS & -0.000752 & 0.2795 & -1.083436 & 0.000694 \\
& R $^{2}$ & 0.526179 & & & \\
Short Run & C & 0.309657 & 0.1225 & 1.549347 & 0.199863 \\
& ROE(-1) & 0.495333 & 0.0000 & 11.21764 & 0.044157 \\
& DTAR & -0.258003 & 0.0813 & -1.750130 & 0.147419 \\
& EA_TA & -0.112652 & 0.6267 & -0.486983 & 0.231326 \\
& NE_DEPOSITS & -0.000388 & 0.4593 & -0.741097 & 0.000524 \\
& R & 0.708653 & & & \\
\hline
\end{tabular}

In the above table you can see that the relationship between the components of liquidity risk and the return on equity is showing slight nuances of change. For instance, the relationship between the DTAR and the ROE has now become negatively significant, at a $1 \%$ significance level. The association between the EA_TA, NE_Deposits and the ROE, however, remained insignificant, even in this model. Also, in the short run model, the relationship between the DTAR and the ROE has now become negatively significant at a $10 \%$ significance level. Furthermore, the association between the EA_TA, NE_Deposits and the ROE, however, have remained insignificant even in this model.

\section{Conclusion}

This section elucidates the summary of the main conclusions of this study, and the plausible directives for the future researches that will follow. The summary is conducted in accordance with the aims of the study, centred on the results of the statistical analysis that is channelled to investigate the hypothesis that has been proposed herein. The findings of this current study reveal that the financial performance of the banks present in Pakistan is negatively, and significantly influenced by the credit risk. This means that the profits experience a reduction when the banks are more exposed to the credit risk. The negative link between the NPLR and the ROE is quite evident by the fact that the commercial banks accept the deposits, and utilize these deposits in order to provide loans, and cover the costs that are linked to the loans. This too tends to diminish the banks' profitability margin. Our study, however, reveals that the lesser the nonperforming loans, the lower the risk factor. The deposits to total assets ratio, the earning assets to total assets ratio, and the net equity to total 
deposits ratio have been used as a proxies for the liquidity coverage ratio (LCR) and the net stable funding ratio (NSFR). The deposits to total assets ratio have come out to be negatively associated with the ROE in the fixedfixed model. Therefore, to sum up, the financial risk comprising of the credit risk and the liquidity risk has a strong impact on the overall enactment of the commercial banks in Pakistan.

The current study facilitates in analyzing how the financial performance of the banks is impacted by the overall financial risk. However, it cannot include all the risks that are associated with commercial banks, and there is a dire need to examine the impact of those other risks as well. This includes the risks that could be imposed on the banks for instance, reputational, technological, legal and other strategic risks, etc. The current study only utilizes the date from the fiscal year 2008 to the fiscal year 2018. Another study can capture an even longer period of time that dates back to before the fiscal year 2008. Also, a similar research can be conducted on other depository institutions for instance, the microfinance banks, and savings institutions, as a comparison study can also be undertaken in this context, as these institutions are giving major competition to the commercial banks. Also a comparison between the Islamic and Conventional banks can also be done, in order to capture the differences in the risk impact that is imposed on both types of banks. 


\section{References}

Abbas, A., Haider, A., \& Rana, U. A. (2014). Credit risk exposure and performance of banking sector of Pakistan. Journal of Basic and Applied Sciences, 4(3), 240-245.

Abiola, I., \& Olausi, A. S. (2014). The impact of credit risk management on the commercial banks performance in Nigeria. International Journal of Management and Sustainability, 3(5), 295-306.

Al-Tamimi, H. A. H., \& Al-Mazrooei, F. M. (2007). Banks' risk management: A Comparison Study of UAE National and Foreign Banks. The Journal of Risk Finance, 8(4), 394-409.

Arif, A., \& Anees, A. N. (2012). Liquidity risk and performance of banking system. Journal of Financial Regulation and Compliance, 20(2), 182-195.

Athanasoglou, P., Delis, M., \& Staikouras, C. (2006). Determinants of bank profitability in the South Eastern European region (Working Paper No. 10274). Bank of Greece, Greece.

Cebenoyan, A. S., \& Strahan, P. E. (2004). Risk management, capital structure and lending at banks. Journal of Banking E Finance, 28(1), 19-43.

Central Bank of Barbados (2008), Liquidity Risk Management Guideline, Bank Supervision Department, Central Bank of Barbados, Bridgetown.

Chaplin, G., A. Emblow, I. Michael, (2000). Banking System Liquidity: Developments and Issues. Bank of England Financial Stability Review, (Dec), 93-112.

Cooper, M. J., Jackson III, W. E., \& Patterson, G. A. (2003). Evidence of predictability in the cross-section of bank stock returns. Journal of Banking E Finance, 27(5), 817-850.

Diamond, D.W., \& Rajan, R.G., (2001). Liquidity Risk, Liquidity Creation and Financial Fragility: A Theory of Banking. Journal of Political Economy, 109(2): 287-327.

Drehmann, M., Sorensen, S., \& Stringa, M. (2010). The integrated impact of credit and interest rate risk on banks: A dynamic framework and stress testing application. Journal of Banking E Finance, 34(4), 713729. 
Falconer, B. (2001). Structural liquidity: the worry beneath the surface. Balance Sheet, 9(3), 13-19.

Goddard, J., Molyneux, P., \& Wilson, J. O. (2004). The profitability of European banks: a cross-sectional and dynamic panel analysis. The Manchester School, 72(3), 363-381.

Holmström, B., \& Tirole, J. (2000). Liquidity and risk management. Journal of Money, Credit and Banking, 32(3), 295-319.

Jenkinson, N. (2008). Strengthening regimes for controlling liquidity risk: Some lessons from the recent turmoil. Bank of England Quarterly Bulletin, Quarterly, 2, 223-228.

Kashyap, A. K., Rajan, R., \& Stein, J. C. (2002). Banks as liquidity providers: An explanation for the coexistence of lending and deposit-taking. The Journal of finance, 57(1), 33-73.

Lopez, J. A., \& Saidenberg, M. R. (2000). Evaluating credit risk models. Journal of Banking $\mathcal{E}$ Finance, 24(1), 151-165.

Musyoki, D., \& Kadubo, A. S. (2012). The impact of credit risk management on the financial performance of Banks in Kenya for the period. International Journal of Business and Public Management, 2(2), 72-80.

Pasiouras, F. (2008). Estimating the technical and scale efficiency of Greek commercial banks: the impact of credit risk, off-balance sheet activities, and international operations. Research in International Business and Finance, 22(3), 301-318.

Sanusi, J. (2002). Central bank and the macroeconomic environment in Nigeria. Quarterly Review, 3(3), 8-18. 
